\title{
Aspects of Indigenous Medicine in South Western Nigeria
}

\author{
Samuel Oluwole Ogundele \\ Department of Archaeology, University of Ghana, Legon, Accra, Ghana \\ E-mail: oluwoleogundele@yahoo.com
}

KEYWORDS Ethno medicine; culture; training; disease; illness; Ifa divination

\begin{abstract}
The Yoruba people are one of the most popular ethnicities in Nigeria. This is with respect to culture and general education. Their relatively recent ancestors contributed significantly to the evolution of facets of the sociocultural landscape of the New World. Most aspects of the ethnomedicine of the Yoruba are deeply rooted in spiritualism - reflecting the dual character of culture. The activities of babalawo - Ifa divination priest/medical man represent to a great extent, the spiritual component of the Yoruba indigenous medicine. On the other hand, those of the onisegun (the medical expert that relies almost exclusively on herbs and animals for preparing medicines) have to do with observational or empirical evidence. This is measurable! However, both categories unlike Western medical experts put more emphasis on illnesses than diseases (embedded in biological disorder). Training in indigenous medicine, is rigorous and time-consuming especially the Ifa divination system. But there is a great assurance of patronage after graduation. Indeed, many Yoruba people including those belonging to the Western medical fraternity still patronize the indigenous medical experts when faced with chronic health problems. Some diseases and the plants used for combating them are listed here. It seems to us that significant insights can be gained by closely embarking on an elaborate and long-term anthropological research on this ancient knowledge system. This would enable the Yoruba ethnomedicine to rise to a considerable rung of the ladder of health care on a global scale.
\end{abstract}

\section{INTRODUCTION}

The southwestern part of Nigeria is the abode of the Yoruba people with a population of approximately 30 million. This figure constitutes about 21 percent of the total population for the country. Some Yoruba are also located in the modern republics of Benin and Togo. They have been separated from their kinsmen in Nigeria by the Berlin "Wall" built in 1885 by the European powers (Osae and Nwabara, 1982).

Some of the major settlements in Yoruba land are Ibadan, Lagos, Abeokuta, Ijebu-Ode, Ilaro, Ilesha, Okemesi, Ado-Ekiti, Oshogbo, Ilorin and Ile-Ife. Ile-Ife is the popularly accepted religious centre for all the Yoruba people in ancient times. The Yoruba nation has several sub-groups like the Ekiti, Ijesa, Oyo, Egba, Ijebu, Yewa and Igbomina. All these sub-groups speak a variety of dialects of the Yoruba language.

Yoruba land is bounded in the south by the Atlantic Ocean (Akanni, 1992; Balogun, 2000). This serves as one of the major gateways to the hinterland. This geographical location has been very important in shaping the historical, cultural and demographic destinies of southwestern Nigeria. Indeed, the region had contacts with the Western world earlier than other parts of the country. Such a development coupled with the rich archaeological and artistic heritages of
Yoruba land makes it (though arguably) the most sophisticated part of Nigeria.

The experience of the Trans-Atlantic slave trade (starting from about the later part of the $15^{\text {th }}$ century A.D) though a painful one in several senses, enabled the Yoruba in the Diaspora to positively modify parts of the religious and social landscape of the New World. This is with particular reference to Brazil, Cuba, Chile and Puerto-Rico, (Osae and Nwabara, 1982). In this connection, the evolution of Santeria (rooted in the Yoruba system of Ifa divination) could be regarded as a significant and unforget-table turning point in the modern historical process of the New World. Suffice it to say, that Santeria is a syncretism of Yoruba religion and Catholic faith. It is being practiced by large numbers of people in the above mentioned countries.

Yoruba land is characterized by forest vegetation as well as patches of derived savanna types arising basically from human activities like bush burning for agricultural and hunting purposes (Dalziel, 1955). The main occupations of the people, particularly the rural folks (that constitute up to 70 percent of the total population) include farming, fishing, blacksmithing, pottery making and indigenous medical practices.

This paper is an attempt to shed some glimmers of light on the anthropology of indigenous medicine in Yoruba land. This is with a view to 
developing a better understanding of the subject that is indeed, a vibrant part of the socio-cultural and ecological heritage of the people. As an anthropological analysis of an indigenous knowledge system, with considerable complexity and breadth, efforts will be made to situate it within the context of culture and environment. Therefore, it is outside the scope of this work, to pay attention to the chemistry and pharmacology of plants. The study groups include herb sellers, Ifa priests and patients at Ibadan, Abeokuta, Okemesi and Ado-Ekiti.

\section{CONCEPTUAL FRAMEWORK OF INDIGENOUS MEDICINE}

Medicine is the system that a group of humans has developed over a long period of time, in order to ensure its survival and good health. Survival and good health are pre-conditions for the individual and collective progress of the society at any point in time and space. Progress in this regard, is physical, mental and spiritual. Therefore medicine is tied to the apron strings of culture and environment. This underscores the reason why ethnomedicine of any given human group in Africa, is a complex phenomenon straddling both the seen and unseen worlds. In other words, we cannot understand the ethnomedicine of the Yoruba, without probing into the overall culture within which it operates and functions (Ogundele, 2006; Hunter and Whitten, 1982; Andah, 1993).

According to Sir Edward Burnett Tylor (a British anthropologist) in 1871, culture is a complex whole which includes knowledge, belief, art, law, morals, custom and any other capabilities and habits acquired by man as a member of society (Tylor in Haviland, 1999). However, since this definition was given, many others have followed. One important insight we have got in recent times, is that culture is clearly divisible into two broad parts as follows:

1. The actual behaviour of a group of people.

2. The abstract values, beliefs and perceptions of the world underlying the behaviour.

This means that culture is an intricate combination of the seen and unseen phenomena. The observable or empirical dimension of behaviour or culture necessarily derives from the abstract component, in a mutually understandable manner. One of the problematics of cultural researches around the world emanates from the fact that, while members of a given society are able to appreciate and appropriate this relationship and its centrality to their corporate existence and progress, the outsider hardly understands. This arises basically from the pre-conceived, but wrong notion of what should be the standard way of behaving by all human groups, regardless of the diversity of socio-cultural and environmental circumstances.

This mode of thinking creates more epistemological gaps in the data generated by the researcher. However, we recognize the fact that, every culture is unique and dynamic, thus making it possible for it to adapt to new sociocultural and ecological circumstances. But adaptation in this context has to be gradual and systematic so that it becomes beneficial to the affected people. It is not to be forced or imposed on a people by another group. This is to ensure some amount of continuity and orderliness, with respect to the corporate survival and progress of a people. A lack of appreciation and appropriation of the fundamentals of culture makes most "modern" development efforts to assist the technologically weaker peoples around the world unworkable.

Indigenous medical practices are as old as the time of the emergence of the earliest man. These practices involved experimenting with different plants and to a lesser degree, animals with a view to determining whether or not they had therapeutic values. This would serve as the basis for ensuring good health for a community. Much information about ethnomedicine is documented orally. Every environmental set-up, had numerous plants with chemotherapeutic values that mankind can use to treat a wide range of diseases including illnesses at any point in time (Haviland, 1999). But in practical terms, this is not always a simple and straight forward enterprise, and herein lies the gulf between Yoruba ethnomedicine and Western health care solely embedded in the domain of the biomedical germ theory.

\section{CLASSIFYING YORUBA ETHNOMEDICAL SYSTEMS}

Although disease and illness are intricately interlinked, they are not exactly the same thing. Disease has to do with the specific biological disorder being experienced by the person, whereas illness is associated directly with the debilitating effects of the disease. This is often 
as a result of stress and anxiety (Hunter and Phillip, 1982). Managing this illness properly, is as equally important as treating the disease.

All indigenous Yoruba medical experts pay considerable attention to the illnesses of patients. This can be understood against the background of the affected person. For example, the medical practitioner would need to carefully counsel the patient about his health problem in the context of life in general. Praying to the supreme God (Olodumare) is also important. This is a crucial part of the healing process. The details of how this works, cannot be quantified or measured. It is within the domain of abstract values of the Yoruba.

There are two categories of indigenous medical experts based on the types of skills acquired as well as modes of operation. The amount of attention given to the socio-cultural facet of treatment depends on the category to which an expert belongs. Thus for example, we have the following:

\section{Ifa Diviners / Priests/ Healers}

These are locally called the babalawo. The babalawo is an authority in Ifa divination system. $\mathrm{He}$ is able to hear, understand and respond to voices and images of the supernatural beings through Ifa - an ancient secret knowledge system. The babalawo is the bridge between the patient and the gods. These babalawo also serve as priests. If $a$ divination is exclusively for the male members of society.

The babalawo makes use of some artifacts for divination purposes. These include a lidded bowl usually elaborately decorated with engravings. Such engravings are beyond the confines of aesthetics. They are mystical and this reflects the importance of visual arts in Yoruba cosmology, environmental consciousness and social history. Such decorations represent the creative use of the human imagination for effective communication, although restricted to only Ifa initiates. This lidded wooden bowl is called Opon ifa, carved by a specialist in ritual / religious arts.

The Ifa priest uses sixteen sacred palm nuts known as ikin which are put inside the lidded bowl after some sacred powder (milky white in colour) has been spread thinly over it (the wooden bowl). This powder is called iyere osun. The diviner starts the business by pronouncing some words to get the attention of the supernatural beings. He also makes some inscriptions on the powder in the wooden bowl. This is to a large extent, mathematical, philosophical and mystical. It can be legitimately claimed that this exercise, is a crossroads of mathematics, philosophy, mysticism and verbal arts. The palm nuts (ikin) are not commonly used in Ifa divination (Fatunsin, 2002). They are used only on special occasions such as when a very important person in the community is sick or when there is a serious civil or external conflict.

Opele ifa (a necklace-like object) is much more frequently used. This also involves the use of a special wand often elaborately decorated with cowrie-shells and beads to invoke the ancestral spirit of the Ifa cult (Fakanbi, 2005 Personal Communication). The Ifa verses correspond to the verses in the Holy Bible and Koran in several ways. They (Ifa verses) are a storehouse of the indigenous intellectual, religious, social, economic, medicinal and political productions of the Yoruba people. They contain information about the successes and failures of ancient Yoruba in all their endeavours. Contemporary problems, challenges and solutions have their long roots in the ancient knowledge system (Ifa). But only the babalawo (the Ifa diviner / priest / medical expert) has the knowledge as well as the consent of the gods to excavate this vibrant and highly esoteric divination record. This verbal excavation of the ancient store house is to ensure an orderly and healthy society.

The babalawo spends a considerable amount of time with every patient in his shelter or shrine. $\mathrm{He}$ is like a social-service worker in Western culture (Fatunde 2006, Personal Communication). Occasionally, he boasts to his patient about his mystical power as well as the numerous people he has helped medically. This attitude offers some psychological support to the patient. By humanizing medicine in this way, the psychological healing of a patient starts straight away. This is opposed to the Euro-American conception of medical practice that is firmly embedded in technologisation - a process that pays more attention to diseases through the lenses of scientific testing, than the feelings of patients. It is a "veterinary" mindset that makes him (Western medical doctor or Western-trained one) focus almost totally on the biological disorder (disease) at the expense of the associated illness. (Oguntade, 2006, Personal Communication). The babalawo approach to health care delivery 
appears to be gaining ground in recent times, in some parts of the developed world including South Africa. This illness-centred approach is called "Family Medicine" (Olufemi, 2003, Personal Communication).

\section{Medical Practitioners Without Ifa Divination Knowledge}

Medical experts belonging to this category are called onisegun. Both male and female members of society can belong to this group, after acquiring the necessary skills from established local authorities. Although the onisegun pays less attention to the patient than the babalawo, he cannot be compared with the Western medical doctor in terms of prescribing adequate behavioural and social management strategies for combating an illness. The activities of this group (Yoruba indigenous medical experts) are much less esoteric in nature. Therefore, observational or empirical evidence can be obtained and measured. There are no provisions for offering sacrifices, except when a patient falls into the hands of a charlatan or fake doctor.

Many people regardless of their educational statuses are still patronizing this category of indigenous medical practitioners, largely because they treat patients almost exclusively with indigenous drugs obtained from extracts of medicinal plants as well as animal sources. In recent times, more and more Nigerians and the Yoruba in particular, are consulting herbalists or onisegun and even the babalawo. Exorbitant medical bills of charges, in the face of chronic material poverty, of a wide range of people are a major factor bringing about this behavioural change. Consequently, Yoruba ethnomedicine that was once on the threshold of extinction, following its clash with some Western values, has started to regain its lost popularity as a significant component of our cultural heritage. It is important to note that some Western-trained doctors of Yoruba ethnic nation, as well as other groups in the country, end up consulting the babalawo after the Euro-American medicines have failed them.

At this point, the patient (no matter the enormity of his academic status) feels that some supernatural forces or angry ancestors are responsible for his health problems. As far as an average Yoruba person or African in general is concerned, the biomedical germ theory that represents the heart and soul of the Western medical health care is most unacceptable in several senses. This shows the centrality and by extension, indispensability of social history and environment to the emergence of human personality (Ogundele, 2006; Adeniji, 2004).

\section{TRAINING PATTERNS IN YORUBA ETHNOMEDICINE}

The Yoruba indigenous educational system is broad. It is a life-long affair that starts from the cradle and only the grave can end it. Ethnomedicine is an important part of this education. Every Yoruba child, as from about the age of eight years, begins to learn in an informal way, names of local plants as well s their uses. This is in terms of therapeutics and nutrition. Early childhood education in indigenous medicine applies basically to the rural people, who constitute the majority of the population. Every opportunity is turned into a teaching affair by the parent of the child. For example, on the way to the farm, the parent stops to obtain some plants and explains their medical values to his child. In the farm, he does the same thing and gradually such a child becomes knowledgeable about some local plants and the environment in general.

This kind of environmental consciousness is the foundation of sustainable health care in Yoruba land. Not only does the parent or a senior person teach the child about medicinal plants, he also gives instructions on the time of the day a plant can be obtained from the forest. For example, most plants are obtained during the day time and not at night or evening. Leaves or barks of plants are more efficacious for medicine when obtained during the sunny part of the day as a result of photosynthesis. From about 6pm in the evening, up to the next morning about 7am is not good for getting parts of plants for medicinal purposes. This is an aspect of the Yoruba ancient knowledge of plant behaviour or botany, that the contemporary people hardly appreciate because of the impact of Western education on them (Ogundele, 2006; Fakanbi, 2005, Personal Communication).

Almost everybody in rural Yoruba land, has at least, some elementary knowledge of plants and their medicinal values. But those who want to become professional medical experts, must necessarily register for special training with an established herbalist. In this regard, the person (student) has to decide on whether or not to 
become a herbalist (onisegun) or babalawo (Ifa priest / diviner / medical man). The former system is comparatively easier and quicker in scope and character to learn. It is generally outside the domain of esoteric medicine. Depending on the trainer, a learner or student can complete the basics of this category of indigenous medicine within two years, if he is very intelligent and obedient to his boss. This training is usually very intensive.

The student pays some fees (usually) instalmentally and in addition, he offers free services to the trainer. For example, he can jointly with other trainees assist the master in cultivating a garden farm or a farm not too far away from the village. Principles and methods of plant and animal classification and identification form the main component of the introductory work (Anquandah, 1997; Fakanbi. 2005, Personal communication). This is in addition to the rules of hygiene and ethics. Many of these rules or principles are coded in special structures such as taboos and proverbs.

The student also learns the art of turning herbs and parts of animals such as skins and skulls into powder for treating different ailments. This is in addition to knowing the right dosage to give to a patient at any point in time. Trainees are taught to always taste whatever medicine they give to patients in their presence. This is to assure them (the patients) that they are not harmful.

Most Yoruba indigenous medical experts appreciate the importance of offering prayers to the supreme God (Olodumare). This is necessary for enhancing the therapeutic values of the prepared medicines. If a divination approach to Yoruba ethnomedicine is a much more difficult one. Although any male member of the society can learn it, a lot of the babalawo and babalawoin-training, are descendants of Ifa diviners / priests. This appears (based on the available oral traditional data) to be a direct consequence of the esoteric and spiritual dimension of this ageold mode of health care. Training therefore takes up to a minimum of six years for those coming from outside the Ifa divination system. Within this period, the student is initiated into the Ifa cult. It is worth all the troubles afterall, because the Ifa divination system / ethnomedical spiritualism is a serious profession and constant patronage is certain.

It is significant to mention however, that even after graduation; the newly trained babalawo needs to update his knowledge. The system is an unending intellectual, social, religious and medical pursuit. In this regard, humility and perseverance are most desirable.

Additional training is also needed for students coming from within the If a circle (Fatunde, 2006, Personal Communication). Not much is exposed to them when they are within the ages of 8 and 25 years. Maturity is important in order to prevent some misuse of mystical powers. But after this age bracket, the master trainer tries to unlock to the student, in a gradual and systematic way, some of the mysteries and powers enshrined in the ancient knowledge system. He does this, through the lenses of such media as incantations, special folk songs and divination.

All these are usually stored in the human memories, in conformity with the way the ancestors passed on the heritage information to their offspring. This underscores the reason why the profession is a full-time one and also timeconsuming. However, some of these pieces of information can be written down in order to avoid creating gaps. There is great power in the words coming out of the human mouth and the Ifa diviners appreciate this facet of their professional calling. Missing out some essential words while making incantations can lead to lower therapeutic values during the process of treating a patient.

It is the belief of the babalawo that every plant or animal has its esoteric or original name at the time of creation by Olodumare (supreme God). He (babalawo) also believes that most of the plants and animals today were once humans. Their original names and the circumstances of their current situations are embedded in Ifa verses. But only members of the Ifa fraternity can know and understand them. When somebody after the training and necessary ritual calls these names the plants and animals become very 'happy' and can be commanded to run errands for humans. In addition, the therapeutic effectiveness of plants grows higher whenever they are called by their original names. As a result, the babalawo calls these names as he prepares medicines. Suffice it to say, that the story of human evolutionary developments from the lower primate ancestry is also documented in some of the Ifa verses.

This aspect of ethnomedicine can only be appreciated within the framework of spiritualism and deep verbal arts of the Yoruba people. Therefore, it would amount to a serious intellectual miscalculation to use the parameters of Western or "modern" science to analyze and 
interpret Yoruba ethnomedicine in an uncritical fashion. Indeed, we may be cutting ourselves off from major insights about both the seen and unseen worlds, if significant attention is not paid to this spiritual and esoteric component of the people's medical heritage.

\section{SOME HEALTH PROBLEMS AND THEIR TREATMENTS}

Health problems in southwestern Nigeria as indeed, other parts of the global village, are numerous and can be treated or managed to a large extent, by plants having therapeutic contents (Adeniji, 2004; Ayitey - Smith, 1989; Dalziel, 1955; Anquandah, 1997; Fakanbi, 2005, Personal Communication). Some of these are as follows:

1. Jaundice - unripe pawpaw is sliced and put in a bottle of water. This can be taken orally (half a glass of water) twice daily. Drops of this should also be put in the two eyes.

2. Poor Sexual Performance by Men - three big bulbs of onion are ground and put inside a half litre of honey. This should be taken twice daily. But men with pile have to first of all treat it before using this medicine.

3. Peptic Ulcer - some green bananas (Musa sapientum) are dried after the peels have been removed and then ground into powder. This powder should be added to the patient's food at least twice daily.

4. High Blood Pressure (Hypertension) between five and ten big bulbs of onion are ground or pounded, with about an equal mount of garlic. Some ginger is added. All these are put inside a half litre of honey in a container. This mixture should be taken twice daily.

b. Fresh bitter leaves can be squeezed inside a container of some little quantity of water and then swallowed. The patient can chew the leaves as well as. This should be done twice daily. Bitter leaves also have sedative effects.

5. Constipation - pineapples (Ananas comosus) and pawpaw (Carica papaya) can be eaten after heavy meals. These fruits contain enzymes that enable digestion to take place easily. This medicine prevents constipation.

6. Diarrhea and Dysentery - a decoction of leaves of guava (Psidium guajava) is good for treating these. This can be taken up to four times daily.

7. Diabetes Mellitus - extract of sweet potato
(Ipomoea batatas) leaves is very good for treating the disease. The leaves have insulin - like substance. $1 \mathrm{gm}$ of this when taken orally, is as effective as 440 units of insulin.

b. Extract of onion (Allium cepa) contains two active substances that lead to a rise in serum insulin level with the capacity to last for four hours.

c. Cashew plant - the barks of the stem are cooked and taken twice or more daily. It lowers blood glucose level for about three hours.

8. Skin Infections - bitter leaves (Vernonia amygdalina) are squeezed and the water is applied to the affected parts as many times as possible daily.

b. Leaves of lime, guava, lemon grass and bitter leaves are boiled. It is used for bathing. Some quantities of the above leaves are ground and mixed with local soap (Ose dudu). This is in addition to shea-butter (ori) and/or olive oil as well as honey. Any other type of soap can be used if the local soap is not available. Bathing with this soap twice daily is very effective for combating skin infections like eczema and ringworm.

\section{CONCLUSION}

Southwestern Nigeria is the abode of the Yoruba people, although a few of their kinsmen can be found in the southern part of the modern republics of Benin and Togo. This forced separation, was a consequence of the Berlin "Wall" erected in 1885 by the European powers. Ethnomedicine in Yoruba land has enormous complexity and breadth that can only be properly analyzed and interpreted within the framework of culture and environment. Culture is a delicate combination of both the seen and unseen worlds. The latter represents abstract values, belief and perceptions of the world underlying the behaviour that constitutes the former. One part cannot be treated at the expense of the other, without risking the charge of anthropological naivety.

In Yoruba ethnomedicine, the difference and similarity between disease (a result of biological disorder) and illness (a product of social, psychological and cultural factors) are appreciated and appropriated. Not unexpectedly, the indigenous medical practitioner pays a significant amount of attention to the latter. This is at variance with the "veterinary" tendencies of the Western medicine despite its remarkable 
technologisation. Medicine needs to be humanized as well so that the healing process can start with the identification of the doctor, with the socio-cultural experience of the patient. "Modern" medicine has to be done or practised beyond the confines of the biomedical germ theory.

The babalawo and onisegun are being patronized by many people in Yoruba land today, more than some fifteen and twenty years ago. This behavioural change cannot be separated from chronic material poverty of the people in the face of poor leadership. But aside from this, Western medicine is yet to be paying sufficient attention to illnesses.

Training in Yoruba ethnomedicine is rigorous, especially if a person wants to become a babalawo (the esoteric and empirical medical practitioner). At least, he needs to spend six years before graduating and even after this, he has to continue updating his knowledge. If a divination approach to medicine is an unending enterprise or knowledge system. Only the grave can stop him from knowing new things. However, the onisegun (herbalist without the use and knowledge of Ifa divination method) can graduate after a minimum of about two years. Both sexes can go into this form of ethnomedicine.

Health problems - diseases and illnesses in Yoruba land as elsewhere around the world, are numerous. Only a few cases such as jaundice, poor sexual performance by men, high blood pressure and diabetes mellitus as well as their treatments are discussed in this paper. Suffice it to say, that this piece of work is anthropological in nature and as a result, no attempts are made to go into the chemistry and pharmacology of plants. There is no doubt, that the Yoruba ethnomedicine (if properly studied), has a lot of significant insights that can be elaborated upon in order to serve members of the modern global village better than now.

\section{ACKNOWLEDGEMENTS}

I would like to thank Professor J. Anquandah for providing some insights about ethnomedicine in parts of Ghana. I'm equally grateful to the Head of Department of Archaeology, University of Ghana, Legon - Dr. K. Gavua, as well as Mrs. Gertrude Kumaga and Mrs. Elizabeth PokuSarkodee (departmental secretary and her assistant respectively) for their friendship. Last but not least, I'm indebted to my wife - Ayodeji Olajumoke and children - Toyin, Olumide, Laolu and Sanmi. They are my mainstay and great pleasure.

\section{REFERENCES}

Adeniji, M. O. 2004. Herbal Treatment of Human Diseases. Ibadan: YNX International (Nig) Ltd.

Akanni, C. O. 1992. Ogun State in Maps. Onitsha: Rex Charles Publications.

Andah, B.W. 1993. A Celebration of Africa's Roots and Legacy. Ibadan: Fajee Publications Ltd.

Anquandah, J. 1997. "African Ethnomedicine: An Anthropological and Ethnoarchaeological Case Study in Ghana." Africa, 11 (2): 289 - 298.

Ayitey-Smith, E. 1989. Prospects and Scope of Plants Medicine in Health Care. Accra: University of Ghana Press,

Balogun, O. Y. 2000. Senior Secondary Atlas. Lagos: Longman.

Dalziel, J. M. 1955. The Useful Plants of West Tropical Africa. London: Crown Agents for Overseas Government and Administration.

Fakanbi, M. 2005. Personal Communication.

Fatunde, S. O. 2006. Personal Communication.

Fatunsin, A.K. 2002. Music, Dance and Yoruba Culture. Ibadan: National Commission for Museums and Monuments.

Haviland, William, 1999. A. Cultural Anthropology. Fort Worth: Harcourt Brace College Publishers.

Hunter, David, E. and Phillip Whiten. 1982. Anthropology - Contemporary Perspectives. Boston: Little, Brown and Company.

Ogundele, S.O. 2006. Our Ancestors Speak: Cultural Heritage, Knowledge and Development Crises In Contemporary Nigeria. Ibadan: Faculty of Science, Public Lecture Series, University of Ibadan.

Oguntade, B.A. 2006. Personal Communication.

Olufemi, A.O. 2003. Personal Communication.

Osae, T. and S. N. Nwabara. 1982. A Short History of West Africa (A.D. $1000-1800)$. London: Hodder and Stoughton. 